\title{
Evaluation of Hyperbilirubinemia as a New Diagnostic Marker for Acute Appendicitis and its Role in the Prediction of Appendicular Perforation
}

\author{
Dr. A. Y. Kshirsagar ${ }^{1}$, Dr. Madhavendra Varadraj Kabra ${ }^{2}$ \\ M.S. Gen Surg., Professor, Department of General Surgery, KIMS Karad, Maharshtra, India \\ ${ }^{2}$ MBBS; Resident, Department of General Surgery, KIMS Karad, Maharshtra, India
}

\begin{abstract}
Aims: 1) Establishment of role of hyperbilirubinemia as a new diagnostic tool to predict gangrenous/perforated appendicitis. Methods: This prospective study conducted on 125 consecutive cases of acute appendicitis admitted to the emergency ward whose serum bilirubin was tested and clinical diagnosis was confirmed perioperatively and post-operatively by histopathological examination. Their data were compiled and analyzed. Statistical analysis was performed using either chi square test or fisher's exact test. Results: Total serum bilirubin including both direct and indirect was found to be significantly increased in case of acute appendicitis. Serum bilirubin was much higher $(P<0.001)$ in cases of gangrenous/perforated appendicitis. Conclusion: Serum bilirubin is an important adjunct in diagnosing the presence of gangrenous/perforated appendicitis.
\end{abstract}

Keywords: Acute appendicitis, gangrenous/perforated appendicitis, hyperbilirubinemia

\section{Introduction}

Appendicitis is one of the commonest causes of abdominal pain requiring emergency surgery. Different clinical signs and symptoms always mimic the diagnosis of acute appendicitis, as there are a number of causes leading to pain in right iliac fossa particularly in female patients. Diagnosing acute appendicitis clinically still remains a common surgical problem. Accurate diagnosis can be aided by additional testing or expectant management or both. These might delay laparotomy and lead to appendiceal perforation with increased morbidity and hospital stay.Elevated Serum Bilirubin level will help in the early and accurate diagnosis of Acute appendicitis and in predicting its serious complications, most importantly the perforation.[1,2,3]

\section{Materials and Methods}

This was a prospective study conducted by the department of Surgery at Krishna Institute of Medical Sciences, Karad from November 2013 to June 2015.125 consecutive cases of acute appendicitis admitted in general surgery department of Krishna Hospital, Karad were recruited in the study. These were subjected to investigation to support the diagnosis.Patients were clinically evaluated by detailed history, routine examination on initial contact with patients and the following investigations were done; complete hemogram, liver function test (LFT), kidney function test (KFT), blood sugar, serum proteins, X-ray chest posteroanterior (PA) view. These investigations blood samples were drawn within half an hour of presentation in the emergency department and radiological investigations were done within 2 hours of admission. Determination of SB was done with photometric testing using 2,4dicholoroaniline.These cases were operated and clinical diagnosis was confirmed per-operatively and postoperatively by histopathological examination.

\section{Inclusion Criteria}

Patients of 15 years of age and above scheduled for appendectomy for acute appendicitis at the emergency unit of our hospital.

\section{Exclusion Criteria}

1) Age below 15 years;

2) Patients with appendicular lump;

3) Appendectomy performed incidentally or for other indications:

4) History of alcoholic liver disease; hemolytic or liver diseases associated with hyperbilirubinemia, gastrointestinal or hepatopancreatobiliary malignancy in the past.

\section{Statistical Analysis}

Statistical analysis was performed. Data were checked for normality before statistical analysis. Normally distributed continuous variables were compared using the unpaired $t$ test. Categorical variables were analyzed using either the chi square test or Fisher's exact test. The area under the curve, the sensitivity, and the specificity was calculated to analyze the diagnostic value of all these markers. For all statistical tests, a $\mathrm{P}$ value $<0.05$ was considered statistically significant.

\section{Observations and Results}

\section{General Characteristics}

Of 125, 95 cases were male and 30 female. Their duration of symptoms ranged from 1-5 days.

Table 1

\begin{tabular}{|c|c|c|}
\hline Sex & No. of cases & Percent \\
\hline Males & 95 & $76 \%$ \\
\hline Females & 30 & $24 \%$ \\
\hline
\end{tabular}




\section{International Journal of Science and Research (IJSR) \\ ISSN (Online): 2319-7064}

Index Copernicus Value (2013): 6.14 | Impact Factor (2015): 6.391

Table 2: Distribution of cases according to histopathological diagnosis

\begin{tabular}{|c|c|}
\hline Histopathological diagnosis & No. of Cases \\
\hline Acute appendicitis & 105 \\
\hline Gangrenous appendix & 8 \\
\hline Perforated appendix & 12 \\
\hline Normal appendix & 0 \\
\hline Total & 125 \\
\hline
\end{tabular}

Table 3: Distribution of the cases according to level of total serum bilirubin (SB) and histological examination

\begin{tabular}{|c|c|c|c|c|}
\hline \multirow{3}{*}{ Histopathology } & \multicolumn{3}{|c|}{ Total Serum Bilirubin } & \multirow{3}{*}{ Total } \\
\hline & $\begin{array}{c}<1.2 \\
\mathrm{mg} / \mathrm{dL}\end{array}$ & $\begin{array}{c}1.2-3 \\
\mathrm{mg} / \mathrm{dL}\end{array}$ & $\begin{array}{c}>3 \\
\mathrm{mg} / \mathrm{dL}\end{array}$ & \\
\hline & No. (\%) & No. (\%) & No. (\%) & \\
\hline $\begin{array}{c}\text { Acute } \\
\text { appendicitis }\end{array}$ & $35(28 \%)$ & $70(56 \%)$ & 0 & $105(84 \%)$ \\
\hline $\begin{array}{c}\text { Gangrenous } \\
\text { appendix }\end{array}$ & 0 & 0 & $8(6 \%)$ & $8(6 \%)$ \\
\hline $\begin{array}{l}\text { Perforated } \\
\text { appendix }\end{array}$ & 0 & 0 & $12(10 \%)$ & $12(10 \%)$ \\
\hline $\begin{array}{c}\text { Normal } \\
\text { appendix }\end{array}$ & 0 & 0 & 0 & 0 \\
\hline TOTAL & $35(28 \%)$ & $70(56 \%)$ & $20(16 \%)$ & $125(100 \%)$ \\
\hline
\end{tabular}

Among 125 cases, total SB (TSB) was raised in 90 (72\%) cases whereas 35 (28\%) cases had normal TSB level. TSB was more elevated in gangrenous and perforated appendix than those in acute appendicitis $(\mathrm{P}<0.001)$. The mean of TSB in acute appendicitis cases without perforation or gangrene was $1.5 \mathrm{mg} / \mathrm{dL}$ and the mean of TSB in cases with perforated or gangrenous appendix was $3.8 \mathrm{mg} / \mathrm{dL}$ (ranged from 3.0- $5.0 \mathrm{mg} / \mathrm{dL}$ ).For gangrenous/perforated appendicitis, the P-value of SB was $<0.001$, specificity $92.9 \%$, sensitivity $100 \%$, positive predictive value $72.7 \%$ and negative predictive value was $100 \%$.

\section{Discussion}

In this study of 125 patients, hyperbilirubinemia was found in 70 of 105 patients with acute appendicitis and in all 20 patients with gangrenous/perforated appendicitis. This hyperbilirubinemia was mixed in type (both conjugated and unconjugated) in most of the patients.

For gangrenous/perforated appendicitis, the P-value of SB was $<0.001$, specificity $92.9 \%$, sensitivity $100 \%$, positive predictive value $72.7 \%$ and negative predictive value was $100 \%$.

The level of SB was higher than $3 \mathrm{mg} / \mathrm{dL}$ in cases of gangrenous/perforated appendicitis while in cases with acute appendicitis it was lower than $3 \mathrm{mg} / \mathrm{dL}(\mathrm{P}<0.05)$. Broadly, we can say that it was predominantly isolated hyperbilirubinemia in the majority of cases.

Our study shows that isolated hyperbilirubinemia without much elevation in the liver enzymes is a significant predictor of appendiceal perforation. This was demonstrated by a study by Estrada et al [4] and other studies [5,6] showing nearly a threefold risk of perforated appendicitis in patients with total bilirubin levels greater than $1 \mathrm{mg} / \mathrm{dL}$.

\section{Summary \& Conclusion}

- It is concluded from our study that elevated TSB (without severe abnormalities in the value of liver enzymes) is a good indicator of Acute Appendicitis.

- If TSB can be added to already existing laboratory tests, then the diagnosis of Acute Appendicitis with clinically suggestive signs can be made with fair degree of accuracy and unnecessary or delay in appendicectomy can be avoided.

- Total serum bilirubin appears to be a new promising laboratory marker for diagnosing appendicular perforation.

The patients with clinical signs and symptoms of appendicitis and with hyperbilirubinemia should be identified as having a higher probability of appendicular perforation suggesting, total serum bilirubin levels have a predictive potential for the diagnosis of appendicular perforation.

\section{References}

[1] Courtney M. Townsend et al. Sabiston Text Book Of Surgery, 18th edition, Philadelphia: Saunders, An Imprint of Elsevier; 2008.

[2] F. Charles Brunicardi et al. Schwartz's Principles Of Surgery. 9th ed. McGraw Hill; 2010

[3] Williams N S, Bullstrode C JK, O'Connell P R. Bailey \& Love's Short Practice of Surgery, 25th Edition.

[4] Estrada JJ, Petrosyan M, Barnhart J, et al. Hyperbilirubinemia in appendicitis: a new predictor of perforation. 2007;11:714-718.

[5] Bennion RS, Baron EJ, Thompson JE. The bacteriology of gangrenous and perforated appendicitis- revisited. Ann Surg 1990;211:165-171.

[6] Bennion RS, Thompson JE, Baron EJ, Finegold SM. Gangrenous and perforated appendicitis with peritonitis:treatment and bacteriology. ClinTher 1990;12:31-44. 